\title{
Serum Leukocytes in Patients with Keloid
}

\author{
Felipe Contoli Isoldii* ${ }^{*}$, Bernardo Hochman ${ }^{2}$, Fabianne Furtado ${ }^{3}$, Yara Juliano ${ }^{4}$ and Lydia Masako Ferreira ${ }^{5}$ \\ ${ }^{1}$ Federal University of São Paulo, Brazil
}

${ }^{2}$ Department of Surgery \& Head of the Pathological Scar Unit, Federal University of São Paulo, Brazil

${ }^{3}$ Federal Institute of Southeast of Minas Gerais (IF Sudeste MG), Brazil

${ }^{4}$ Department of Collective Health, Santo Amaro University, Brazil

${ }^{5}$ Department of Plastic Surgery \& Surgery, Federal University of São Paulo, Brazil

Submission: September 26, 2017; Published: November 14, 2017

*Corresponding author: Felipe Contoli Isoldi, MD-Post graduate Program, Federal University of São Paulo (Unifesp), São Paulo, Napoleão de Barros st, number 715- 4th floor, Vila Clementino, São Paulo/SP- PO Box: 04024-002, Brazil, Tel: 551155764118; Fax: 551155716579;

Email: felipeisoldi@gmail.com

\begin{abstract}
Background: The mechanisms underlying the pathogenesis of keloids have not been fully characterized. Results of past and present studies have shown that the immune system is actively involved in the development of these lesions. The occurrence of leukocyte infiltration into keloid tissue, and increase in serum immunoglobulinshave been demonstrated; however, no study to date has evaluated serum leukocyte counts and leukocyte distribution in patients with keloids.
\end{abstract}

Materials and methods: Samples of venous blood were collected from 21 patients with keloids and 20 patients with normotrophic scars for total and differential leukocyte counts.

Results: There were no significant differences neither in mean total leukocyte counts $(\mathrm{p}<0.343)$, nor in differential leukocyte counts (neutrophil, $\mathrm{p}<0.444$; eosinophil, $\mathrm{p}<0.620$; basophil $\mathrm{p}<0.515$; monocyte, $\mathrm{p}<0.688$; and lymphocyte, $\mathrm{p}<0.439$ ) between groups.

Conclusion: No quantitative and qualitative differences were found in leukocytes counts between patients with and without keloids. This confirms the fact that keloid scarring is not an intrinsic disturbance that results in increased cell proliferation. According to this view, keloid scarring may be regarded as an inflammatory disturbance related more to cellular hypermetabolism than to cell hyperproliferation.

Keywords: Keloid; Inflammation; Leukocytes; Leukocytes Count; Wound Healing

\section{Introduction}

Keloid formation results from a disturbance in wound healing caused by an imbalance between collagen synthesis and degradation; however, the mechanisms underlying keloid pathogenesis are not well understood [1]. Keloids are benign neoplasms that grow beyond the boundaries of the original wound. They do not regress spontaneously, and have a high recurrence rate after excision, even when the procedure is combined with other treatment modalities. The condition is characterized by pruritus, pain and hyperemia, suggesting an intermittent, local inflammatory process [2].

An increase in the metabolic activity of fibroblasts, and consequent increase in collagen synthesis, may occur due to a prolonged chronic inflammatory process [3]. This process is characterized at the cellular level by an increase in neutrophils, mast cells, lymphocytes and macrophages [4,5]. In this context, Hazrati \& Hoomand [6] observed by microscopy a significantly higher tissue infiltration by these inflammatory cells in keloids than in spinocellular carcinoma. These authors also demonstrated the association between local lymphocytic infiltration and serum lymphocytosis, and exacerbation of immediate and delayed hypersensitivity skin reactions in patients with keloids $[7,8]$.

The relationship between keloid and the immune system $[4,7]$ becomes more important in patients with keloids and high serum IgE levels [8]. This immunoglobulin induces mast cell degranulation, which triggers proinflammatory signaling, which in turn will induce collagen deposition [7].

Immunoglobulins $\mathrm{G}, \mathrm{M}$ and $\mathrm{A}$, and the $\mathrm{C} 3, \mathrm{C} 4$ and $\mathrm{C} 1 \mathrm{q}$ complement components have been associated with keloid formation; however, there is divergence in the literature 
concerning their level variation in patients with keloids [4,5]. On the other hand, it has been established that atopic patients are more susceptible to develop keloids [9].

Despite the fact that all evidences point to a relationship between the immune system and the pathogenic mechanisms of keloids, no studies were found in the literature evaluating serum leukocyte counts in patients with keloids. Therefore, the aim of this study was to investigate serum leukocyte counts and leukocyte distribution in patients with keloids.

\section{Materials and Methods}

This controlled study was conducted with 41 patients who attended the Plastic Surgery Outpatient Clinic of the Federal University of São Paulo. Participants were selected and divided into two groups: Keloid Group (KG: $n=21 ; 6$ men; median age, 29 years), and Control Group (CG: $n=20 ; 14$ men; median age, 23 years).

The keloid group consisted of patients with keloid scars located on the trunk, including the region between the transverse plane at the level of the sternoclavicular joint and transverse plane at the level of the upper margin of the pubic symphysis, comprising the whole-body perimeter. Patients with keloids of more than 1-year duration, which were showing clinical activity, such as pruritus, pain and hyperemia, alone or in combination, were included in this group. The control group included patients with normotrophic scars of more than 1-year duration, without past or current keloid or hypertrophic scars. Patients with treated or recurrent keloids of less than 1-year duration following previous excision, collagen disorders, malignant neoplasia, or those who underwent chemotherapy or corticoid treatment were excluded from the sample.
All patients responded to a medical history questionnaire, which also included questions on the characteristics of the keloid (location, presence of local pruritus, pain and hyperemia, causes of keloid formation, and keloid duration) and history of atopy. Scar pain and pruritus were measured using a visual analogue scale (VAS) rated from 0 (no symptom) to 10 (maximum symptom intensity) [10]. After, a venous blood sample was taken from the forearm of each patient for total and differential leukocyte counts. All laboratory tests were performed by the Central Laboratory at the Federal University of São Paulo Hospital (Unifesp).

Student's t-test was used to compare the mean absolute count of each leukocyte cell type (neutrophils, eosinophils, basophils, monocytes, and lymphocytes) at a significance level of $0.05(\mathrm{p}<$ 0.05).

The present study was approved by the Research Ethics Committee of the Federal University of São Paulo (Unifesp), Brazil, and was performed in accordance with the ethical standards laid down in the 1964 Declaration of Helsinki. Written informed consent was obtained from all patients. Patient anonymity was assured.

\section{Results}

With regard to atopy, $24.4 \%$ of the patients in the keloid group and $17.1 \%$ of the patients in the control group had allergic rhinitis and contact dermatitis according to the medical history questionnaire.

There were no significant differences either in mean total leukocyte counts or differential leukocyte counts (neutrophils, eosinophils, basophils, monocytes, and lymphocytes) between groups (Table 1).

Table 1: Mean absolute counts of differential leukocytes (neutrophils, eosinophils, basophils, monocytes, and lymphocytes) and total leukocytes in the keloid $(n=21)$ and control $(n=20)$ groups.

\begin{tabular}{|c|c|c|c|c|c|}
\hline Leukocytes & Groups & Mean Count (cells $/ \mathbf{m m}^{3}$ ) & SD & SE & p-Values \\
\hline \multirow{2}{*}{ Neutrophils } & Keloid & 3656.19 & 1630.665 & 355.84 & \multirow{2}{*}{0.444} \\
\hline & Control & 3333.7 & 965.38 & 216.76 & \\
\hline \multirow{2}{*}{ Eosinophils } & Keloid & 156.56 & 161.734 & 35.293 & \multirow{2}{*}{0.62} \\
\hline & Control & 179.01 & 124.673 & 27.878 & \\
\hline \multirow{2}{*}{ Basophils } & Keloid & 68.94 & 39.077 & 8.527 & \multirow{2}{*}{0.515} \\
\hline & Control & 61.05 & 37.766 & 8.445 & \\
\hline \multirow{2}{*}{ Lymphocytes } & Keloid & 2173.26 & 772.235 & 168.515 & \multirow{2}{*}{0.439} \\
\hline & Control & 2011.2 & 538.308 & 120.369 & \\
\hline \multirow{2}{*}{ Monocytes } & Keloid & 458.4 & 151.246 & 33.005 & \multirow{2}{*}{0.688} \\
\hline & Control & 477.83 & 156.098 & 34.905 & \\
\hline \multirow{2}{*}{ Total Leukocytes } & Keloid & 6571.43 & 2009.807 & 438.576 & \multirow{2}{*}{0.343} \\
\hline & Control & 6068 & 1277.253 & 285.602 & \\
\hline
\end{tabular}




\section{Discussion}

The present study was based on the work of Hazrati \& Hoomand [6], who raised the hypothesis that patients with keloids did not have the tendency to develop spinocellular carcinoma and viceversa. This proposition was based on inflammatory parameters; the authors observed increased lymphocyte count in the serum and tissue of patients with keloids, and exacerbation of immediate and delayed hypersensitivity skin reactions in patients with skin carcinoma. Their study was conducted with 68 patients.

When compared with patients with normal skin, patients with keloids have increased levels of immunoglobulins, complement components, and pro-inflammatory cells $[3,4,7,8]$, as in the lymphocyte infiltrate, containing high concentrations of T-cells (CD3+, CD4+, CD45RO+, and HLA-DR+), dendritic cells (CD1a+, CD36+, HLA-DR+, and ICAM-1+), macrophages, and mast cells $[4,5,7]$. This increase in cell number definitely demonstrated that the immune system is constantly active [4], recruiting elements for regulation of inflammation in the keloid tissue [1,2]. These phenomena imply that the existence of a systemic inflammatory state would provide an appropriate microenvironment for keloid formation and growth [2].

Keloid fibroblasts produce more collagen than normal skin fibroblasts [1,2]. However, there are no differences in growth and proliferation between keloid and normotrophic scar fibroblasts [11]. Therefore, the increased collagen production in keloids is related to an increase in fibroblast activity, characterizing a hyperactive state of these cells, which results in higher energy consumption [12]. Hyperactivity of fibroblasts is associated with deregulation of cytokines, interleukins, and growth factors (especially TGF-beta) [2], which have proven to induce keloid growth. Hence, after its development, the keloid itself creates a self-perpetuating cycle [2].

However, in the present study, there were no significant differences in the total and differential leukocyte counts between patients with and without keloids. These results confirm the fact that keloid scarring is not an intrinsic disturbance that results in increased cell proliferation, as demonstrated with respect to keloid fibroblasts (no quantitative differences between keloid and normal skin fibroblasts were detected). Keloid fibroblasts show increased activity, resulting in increased collagen synthesis, rather than increased proliferation. According to this view, keloid scarring should be regarded more as a disturbance in cellular hypermetabolism than as a disturbance in cell hyperproliferation $[1,13]$. This may explain the results with respect to serum leukocytes.

In comparison with the control group, the keloid group had a higher prevalence of atopy, pruritus, pain, and hyperemia, of which pruritus was the most frequent symptom. This is in agreement with the literature [1,9]. These symptoms are indicative of a neurogenic inflammatory activity intrinsic to the keloid that is represented by the presence of a large number of nociceptive nerve endings in this tissue [14], higher levels of proinflammatory neuropeptides, such as CGRP [15], and a functional disturbance of this innervation $[14,15]$.

Although the presence of the Immune System in the genesis and maintenance of the inflammatory process involved in keloid is verified at serum and histological levels, leukocytes quantification in the peripheral blood was not altered. Even when the keloid presented exacerbated clinical symptoms. The present study suggests that further research is necessary to investigate differences in a possible systemic inflammatory state, either in the level of cell signaling or gene expression, in patients with keloids.

\section{Conclusion}

In conclusion, there are no quantitative and qualitative differences in serum leukocyte counts in patients with keloids.

\section{Acknowledgement}

Tribute is paid to the great master Professor Bernardo Hochman. This is a posthumous tribute to him; he devoted much of his life to studying, understanding, teaching and disseminating what the keloid really is. We will forever remember his words "If the eyes are the mirror of the soul, the skin is the mirror of the mind".

\section{References}

1. Berman B, Maderal A, Raphael B (2017) Keloids and hypertrophic scars: pathophysiology, classification, and treatment. Dermatol Surg 43 (Suppl 1): S3-S18.

2. Ogawa R (2017) Keloid and hypertrophic scars are the result of chronic inflammation in the reticular dermis. Int J Mol Sci 18(3). pii: E606.

3. Jumper N, Paus R, Bayat A (2015) Functional histopathology of keloid disease. Histol Histopathol 30(9): 1033-1057.

4. Bagabir R, Byers RJ, Chaudhry IH, Müller W, Paus R, et al. (2012) Site-specific immunophenotyping of keloid disease demonstrates immune upregulation and the presence of lymphoid aggregates. Br J Dermatol 167(5): 1053-1066.

5. Boyce DE, Ciampolini J, Ruge F, Murison MS, Harding KG (2001) Inflammatory-cell subpopulations in keloid scars. Br J Plast Surg 54(6): 511516.

6. Hazrati E, Hoomand A (1977) The keloidal diathesis, a resistant state to malignacies? Plast Reconstr Surg 59(4): 555-559.

7. Douaiher J, Succar J, Lancerotto L, Gurish MF, Orgill DP, et al. (2014) Development of mast cells and importance of their tryptase and chymase serine proteases in inflammation and wound healing. Adv Immunol 122: 211-252.

8. Bloch EF, Hall MG, Denson MJ, Solomon VS (1984) General immune reactivity in keloid patients. Plast Reconstr Surg 73(3): 448-451.

9. Hajdarbegovic E, Bloem A, Balak D, Thio B, Nijsten T (2015) The Association between atopic disorders and keloids: A case-control study. Indian J Dermatol 60(6): 635.

10. Kremer E, Atkison JH, Ignelzi RJ (1981) Measurement of pain: patient preference does not confound pain measurement. Pain 10(2): 241-248.

11. Lim IJ, Phan TT, Bay BH, Qi R, Huynh H, etal. (2002) Fibroblasts cocultured with keloid keratinocytes: normal fibroblasts secrete collagen in a keloidlike manner. Am J Physiol Cell Physiol 283(1): C212-C222. 
12. Wulandari E, Jusman SW, Moenadjat Y, Jusuf AA, Sadikin M (2016) Expressions of collagen I and III in hypoxic keloid tissue. Kobe J Med Sci 62(3): E58-E69.

13. Hu ZC, Shi F, Liu P, Zhang J, Guo D, et al. (2017) TIEG1 represses smad7mediated activation of TGF- $\beta 1 /$ Smad signaling in keloid pathogenesis. J Invest Dermatol 137(5): 1051-1059.
14. Hochman B, Nahas FX, Sobral CS, Arias V, Locali RF, et al. (2008) Nerve fibres: a possible role in keloid pathogenesis. Br J Dermatol 158(3): 651652.

15. Akaishi S, Ogawa R, Hyakusoku H (2008) Keloid and hypertrophic scar: neurogenic inflammation hypotheses. Med Hypotheses 71(1): 32-38.

\section{Your next submission with Juniper Publishers will reach you the below assets}

- Quality Editorial service

- Swift Peer Review

- Reprints availability

- E-prints Service

- Manuscript Podcast for convenient understanding

- Global attainment for your research

- Manuscript accessibility in different formats ( Pdf, E-pub, Full Text, Audio)

- Unceasing customer service

Track the below URL for one-step submission https://juniperpublishers.com/online-submission.php 